\title{
The appropriation of the book of Jonah in 4th century Christianity by Theodore of Mopsuestia and Jerome of Stridon
}

\begin{abstract}
The book of Jonah (c. 430-330 BCE) is one of the Old Testament books that was received in its Septuagint version in Early Christianity. This paper deals with the two earliest extant commentaries on the book of Jonah: the Greek commentary by Theodore of Mopsuestia (written in the last quarter of the 4th century) and the Latin commentary by Jerome (396 CE). Written independently at about the same time, both comment verse-by-verse on the whole book of Jonah. We will investigate and compare the two authors' communicative strategies within a triangle of pretext, readership, and commentary, i.e. which techniques they employ in order to appropriate the c. 800 year old, canonical book of Jonah to its contemporary readers, how they interpret their current situation by means of reception of the ancient text, which norms and values they derive from it, and to what extent they attribute to it a formative effect concerning Christian identity in their own times.
\end{abstract}

\section{Introduction}

The book of Jonah (c. 430-330 BCE) is one of the books of the Hebrew Bible that was received in its Septuagint version in Early Christianity, though in quite different aspects: Matthew 12:39-41 (c. 80 CE) offers a Christological interpretation of Jonah's three-day stay in the belly of the fish, whereas the fresco paintings and sarcophagus reliefs in the Roman catacombs (3rd century $\mathrm{CE})$ apply Jonah's rest under the plant to the eschatological rest of the individual Christian. ${ }^{1}$ These divergent traditions of Jonah-reception form the background of the two earliest extant commentaries on the book of Jonah: the Greek commentary by Theodore of Mopsuestia - the most important exegete of the School of Antioch (written in the last quarter of the 4th century) - and the Latin commentary by Jerome (396 CE). Written independently at the end of the 4th century CE, both comment verse-by-verse on the whole book of Jonah.

1 For an overview, see Dresken-Weiland 2010, 96-118; Paul 1970.

כ Open Access. (c) 2020 Katharina Bracht, published by De Gruyter. (cc) BY-NC-ND This work is licensed under a Creative Commons Attribution-NonCommercial-NoDerivatives 4.0 International License.

https://doi.org/10.1515/9783110557596-026 
Both traditionally are titled Commentarius in Ionam prophetam (abbreviated Ion.). This paper will investigate and compare the two authors' communicative strategies within a triangle of pretext, readership, and commentary: which techniques do they employ in order to appropriate the c. 800 year old, canonical book of Jonah to their contemporary readers; ${ }^{2}$ how do they interpret their current situation by means of the reception of the ancient text; which norms and values do they derive from it, and to what extent do they attribute to it a formative effect concerning Christian identity in their own times?

\section{The biblical pretext: the book of Jonah}

The book of Jonah is included within the Hebrew Bible in the so-called Book of the Twelve Prophets. In the Hebrew canon, it occupies the fifth position in between the prophets Obadiah and Micah. Contrary to the other eleven books of the 'Minor Prophets,' it preserves no prophetic word, but rather belongs to the genre of narrative. ${ }^{3}$ YHWH calls Jonah to announce his judgment against the city of Nineveh. However, Jonah does not want to carry out God's mission, preferring to flee on a ship to Tarshish. After Jonah flees God's mission, a life-threatening storm arises, the lot cast by the sailors determines his guilt, and the sailors throw him into the sea (Jonah 1). YHWH appoints a great fish to swallow him, and it is in that fish's belly where Jonah remains for three days and three nights. During this period of time, Jonah thanks God for his salvation (Jonah 2). After the fish has vomited him back up on land, God commissions Jonah a second time to proclaim his judgment against Nineveh, which will be executed within forty days. This time Jonah obeys. From his brief pronouncement of judgment, people, cattle, and king repent of their evil. Because of their repentance, God decides not to execute the impending disaster he had planned for the city (Jonah 3). When Jonah becomes angry with God on account of his kindness, God appoints a castor-oil plant to grow up near Jonah's booth in order to shade him from the sun; however, a worm and the scorching sun cause the castor-oil plant to wither the next day. Through the destruction of the plant, God shows Jonah

2 Jörg Rüpke points out the benefits of "searching for the readers" for finding out more about lived ancient religion, see Rüpke 2015, 95-98.

3 For a short, yet thorough general introduction on the Old Testament book of Jonah, see Zenger 2016, 664-671. 
that just as he mourns the loss of the castor-oil plant that he did not create, so also God would mourn if he had to destroy the great city of Nineveh with more than 120,000 inhabitants (Jonah 4).

The Hebrew book of Jonah was written during the Second Temple period, possibly around 430-330 BCE. ${ }^{4}$ For the early Christians, however, Jonah was not known in the original Hebrew edition but in the Greek Septuagint translation (LXX), which was translated together with the entire Book of the Twelve Prophets most likely in Egypt - possibly in Alexandria - during the 2nd-1st century BCE, and must have been present, at the latest, in the first half of the 1st century BCE (see Schart 2011, 2282-2283). Within the LXX, the book of Jonah was moved to a new place within the Book of the Twelve Prophets and it resides in the immediate neighborhood of the book of Nahum, which itself is about the city of Nineveh. ${ }^{5}$ The translator strives to produce an accurate but understandable translation. In addition to some minor variants, there are a few significant changes in Jonah ${ }^{\mathrm{LXX}}$ when compared to Jonah ${ }^{\mathrm{Hebr}}$ : Jonah $^{\mathrm{LXX}}$ 2:1f. 11 replaces the fish by a sea monster (kêtos). In Jonah ${ }^{\text {Hebr }}$ 1:9, Jonah calls himself 'a Hebrew' ('bry; cf. Jonah ${ }^{\mathrm{MT}}$ 'ibry); in Jonah ${ }^{\mathrm{LXX}}$, however, he calls himself 'a servant of the Lord' (dúlos kyríu). ${ }^{6}$ According to Jonah ${ }^{\text {Hebr }}$ 3:4, Jonah's proclamation of judgment against Nineveh will not take place for another forty days. This period of time, however, is shortened to only three days within Jonah ${ }^{\mathrm{LXX}} 3: 4^{7} .^{7}$ Instead of a castor-oil plant (Jonah $^{\mathrm{Hebr}}$ 4:6 qyqywn; cf. Jonah ${ }^{\mathrm{MT}}$ qiyqāyōn), it is a type of gourd (kolokýnthē) in Jonah $^{\mathrm{LXX}}$ 4:6. The translator also creates a new Leitwort network by translating the interior of the ship (Jonah $\left.{ }^{\mathrm{LXX}} 1: 5\right)$, the sea monster (2:1), and Hades (2:3) with the same word, koilia (see Heckel 2011, 2395). ${ }^{8}$ The following remarks will show the significance of the different details of the Hebrew or Greek pretexts for the later reception of the book of Jonah.

4 Golka 2001, 569. See Zenger 2016, 669, who assumes that it was written in the 2nd half of the 4th century or in the beginning of the 3rd century BCE.

5 Thus, within the Hebrew canon Jonah is in the fifth position - between Obadiah and Micah - in the Book of the Twelve Prophets, but it is in the sixth position - before Nahum within the LXX canon.

6 This change, however, occurs because of an error in reading the Hebrew text: the translator read the consonants of the Hebrew text 'bry as ' $b d y$ and understood it as an abbreviation for 'bdy yhwh. See Heckel 2011, 2399.

7 According to Heckel 2011, 2402, a Christian interpolation in the LXX cannot be excluded.

8 Heckel 2011, 2395. 


\section{A metatext: Theodore of Mopsuestia, Commentary on Jonah (c. 375-400 CE)}

\subsection{Introductory questions: author and writing}

Theodore was born around $350 \mathrm{CE}$ in Antioch of Asia Minor. He initially studied there with the famous pagan rhetorician Libanius before he entered, at the age of 20 - together with his study friend, John Chrysostom - into the monastery (askētếrhion) of Diodorus (who later became the Bishop of Tarsus; see Theodoretus of Cyrus, Historia ecclesiastica 5.40.1). From Diodorus, the founder of the Antiochean exegetical school (Fuhrer 2002, 199-200), Theodore and John Chrysostom learned to be wary of an exclusively allegorical-mystical interpretation of Scripture and also learned the method of literal-historical exegesis, which Theodore uses in his Jonah commentary. ${ }^{9}$ In 392/93, he was ordained bishop of the Cilician city of Mopsuestia and occupied this position for 36 years. In $553 \mathrm{CE}$, he was posthumously anathematized which led to the almost complete destruction of his dogmatic literature in its original Greek. ${ }^{10}$ His Jonah commentary is part of a larger work, the Commentary on the Twelve Prophets, which he wrote during the last quarter of the 4 th century. ${ }^{11}$ Theodore wrote this commentary during his time as a monk in the Antiochian monastery, and it is his only work that has been completely preserved in the Greek original (Bruns 2002). Theodore's work is the oldest, completely preserved Christian commentary on the entire book of Jonah (Dassmann 1998, 681).

\subsection{The reader community in Antioch}

The term "reader community" is to be understood in two respects: (1) Theodore writes his Commentary on the Twelve Prophets for a concrete reader or listener about whom he provides no information (see Hill 2004, 15). I assume that he looked first to his fellow monks in the monastery in Antioch as an audience and to his school context (see Schäublin 1981, 763-764) as the commentary's Sitz

9 For an extensive treatment of Theodore's method, see Schäublin 1974, 84-155.

10 It is only thanks to the already existing Syrian translation that Theodore's dogmatic writings remain intact. See Bruns 2002, 678.

11 See Duval 1973, 57, 212. Perhaps it is, as Robert C. Hill suspects, a work from his youth, which he wrote before his ordination as a priest and appointment as a bishop. See Hill 2001, 107-129; compare Hill 2004, 4: "this piece of juvenilia"; 15: "before his being ordained priest in his thirties." 
im Leben. (2) Theodore feels that he is connected with his Antiochian Christian audience or readership, ${ }^{12}$ as is evidenced and expressed by his occasional use of the inclusive 'we,' to form a community that received the Book of the Twelve Prophets as authoritative for and written to them. ${ }^{13}$

Theodore presents the biblical book of Jonah in the LXX translation, ${ }^{14}$ the text version that possessed canonical standing as the "Bible of the first Christians." That Theodore attaches such authority to the Greek edition of the Book of the Twelve Prophets is confirmed by the fact that he treated it as a closed text and reproduced it within his commentary unchanged (see Sprenger 1977:1, 72; Assmann 1995, 28-30). ${ }^{15}$ Accordingly, Theodore and his audience expected that this old text would have a normative and formative effect for their community, which is not, however, able to naturally unfold because of the "expansion of the communicative situation” (“Zerdehnung der Kommunikationssituation”, see Assmann 1995). The temporal distance - around 800 years in reference to the writing of the Hebrew book of Jonah and 500 years in reference to its Greek translation - between the canonical pretext and Theodore's contemporary audience is too vast and the religious differences between the original audience of the Hebrew book of Jonah or the early Jewish audience of the LXX and the actual Christian audience (Theodore and his addressees) are too large. ${ }^{16}$ The need arises, therefore, to explain the canonical (closed, unchangeable) text with the help of a meta- or paratext in order to produce the normative and formative effect that is expected from it (Assmann 1995, 28).

From other sources, there are some things - not altogether too many - to be said about the situation of the Antiochian "reader community". In the second half of the 4th century, Antioch was "a vital metropolis ... where the cultural and economic forces of the East (as far as Persia) and the West (as far as Rome) met" (Kondoleon 2000, 4). Two generations had already passed since the so-called

12 For antiquity we have to assume hearers more often than readers, because texts used to be read out for a community of listeners, see Bracht 2014, 125-126, specifically n. 109; Rüpke 2015, 97.

13 See, for example, Theodore of Mopsuestia, Ion. prooem. (169,14-20 Sprenger); Ion. 3.2 (185.19 Sprenger).

14 His biblical text is the oldest textual witness to the Lucian recession. See Sprenger 1977:1, 63.

15 However, Theodore's pretext follows the canonical order of the Hebrew Bible (i.e. Jonah stands in the fifth position within the Book of the Twelve Prophets, before Micah); see also Hill 2004, 16. Despite the fact that his pretext reflects the canonical order of the Hebrew text, Theodore nevertheless references the book of Nahum. See Ion. prooem. (176,14-21 Sprenger).

16 The geographical distance between Alexandria and Antioch, about $1500 \mathrm{~km}$, plays a comparatively small role in the cultural context of the surrounding Mediterranean area. 
Constantinian shift and the end of Christian persecutions. Within Antioch, there existed one of the largest Jewish diaspora communities of late antiquity (see Hahn 1996, 62f.). Its influential leadership was Greek (Hahn 1996, 69-71). The contact between Jews and Christians was so $\operatorname{good}^{17}$ that a large number of Christians practiced their religion in community with the Jews of the city. John Chrysostom, in his sermons, polemically opposes what he considers as Jewish tendencies in the Christian community, ${ }^{18}$ criticizing that his parishioners were unaware of the fundamental differences between Jewish and Christian faith and unconscious of having a specific Christian identity. Thus the question of the relationship between Jews and Christians struck a chord with the Christians in Antioch at the time of Theodore's Jonah commentary. ${ }^{19}$

\subsection{The commentary}

\subsubsection{Description of the text}

Theodore's Jonah commentary consists of two parts. It begins with an exceptionally long Prooemium, which comprises a total of more than a third of the printed text $^{20}$ (a total of 21 printed pages in Sprenger's edition), followed by a cursory verse-by-verse-commentary. In this part, Theodore usually selects a

17 This information can be gleaned from the eight sermons of John Chrysostom's Adversus Ioudaios (PG 48, 843-942); for a treatment of these texts, see Hahn 1996, 72 n. 42.

18 John Chrysostom objects in vain to the fact that Christian parishioners attend Jewish festivals, participate in Jewish fasting practices, and some even allow themselves to be circumcised according to the Jewish ritual. See Fürst 2011:3, 298-300; Hahn 1996, 74-76, and for supporting evidence 74 , n. 48.

19 The decision of the so-called apostolic council (appr. $50 \mathrm{CE}$ ) that Gentile converts were not obliged to practice circumcision (Acts 15, Galatians 2) paved the way for a parting of the ways of Judaism and Christianity. According to Justin, Dialogue with Trypho (before $165 \mathrm{CE}$ ), the essential difference between Jewish and Christian believers concerned the question whether Jesus of Nazareth was to be regarded as the Messiah. For further discussion on this theme, see the overview by Lindemann 2001. The question in dispute is when the separation between Church and Synagogue should be dated: Dunn 1996, 243 assumes on the basis of his study that "by the end of the second Jewish revolt, Christian and Jew were clearly distinct and separate" (i.e. c. 130/135 CE). The Jewish scholar Daniel Boyarin, however, maintains that the borders between Judaism and Christianity were fluid for much longer and assumes that the separation of "these two complexly intertwined religions and social formations" only was completed as late as in the 4th century, see Boyarin 1999, 114. Our observations on Theodore's Jonah commentary presented in this paper support the dating by Boyarin.

20 Sprenger 1977:2, 169-190 In Ionam; 169,1-176,28 Prooemium. 
lemma within the scope of a partial or an entire verse and offers a brief comment as a paratext. Yet, as a metatext, the comment refers so precisely to the pretext that it is clear that the lemma was chosen by Theodore himself and not added later by a redactor. ${ }^{21}$ However, there are a few verses which Theodore does not quote literally but rather paraphrases them. An epilogue or a concluding doxology are absent, just as they are also absent in Theodore's commentaries on the other books of the Twelve Prophets (see also Hill 2004, 16).

\subsubsection{Strategies of appropriation}

Following the expectations of ancient readers, the Prooemium of Theodore's Jonah commentary establishes a framework for understanding the comments that follow in the remainder of the work. Even with the first, extensive sentence, Theodore sets the parameters within which, in his view, the biblical book of Jonah should be understood, and with the first dozen words he poses the problem and the thesis he desires to undertake: "The God of both the Old and the New covenant is one ...."22 The matter which is up for debate is the relationship between the Old Covenant (in which the biblical book of Jonah originates) and the New Covenant (in which Theodore and his contemporary "reader community" read the book of Jonah); the thesis is that both covenants are connected to one another by the one God, Lord, and Creator, who always has the goal of his plan of salvation (oikonomía) in view and guides his people there. ${ }^{23}$ Set against the background of the pluralistic worldview of contemporary Antiochene society is the current question of the relationship between Jews (those who belong to the Old Covenant) and Christians (those who belong to the New Covenant) as well as the question of what relevance the book of Jonah as a text of the Old Covenant might have for Christians.

After addressing the relationship between the covenants, Theodore sketches a clear and precise dogmatic framework that he axiomatically presupposes: God's plan of salvation (oikonomía) consists of his in-advance presentation to the people of the Old and the New Covenant about the future eschatological goal that he had provided for them. On the one hand, they would thereby better recognize the magnificence of the good things they will receive in comparison ( $e k$

21 Sprenger 1977:1, 64-66, proves that the lemma text is "firmly integrated into the comment" (66).

22 Heís kaí ho aytós té te palaiás kaí néas diathékēs hypárhchōn theós; Theodore of Mopsuestia, Ion. prooem. (169,8f. Sprenger; translation Hill).

23 Theodore of Mopsuestia, Ion. prooem. (169,10.12f.26 Sprenger). 
parhathéseōs) to the present state. On the other hand, it thus becomes clear that from the beginning God both foresaw and foreshadowed the coming of Jesus Christ, which consequently meant that there is no innovation or change within God's plan of salvation. ${ }^{24}$ In Christ, what God promised Abraham and David was fulfilled in a true way (Theodore of Mopsuestia, Ion. prooem. 169,8-29 Sprenger).

In what follows, Theodore clarifies both terminology and other matters: the events (prhágmata) of the Old Covenant were not only beneficial to the people at that time - implying that they historically took place - but were also of a "type," that is a typological foreshadowing of later events (the New Covenant). The former events had a certain resemblance (tis mimēsis) to later ones - inasmuch as they were useful in their time - and were sure and fast announcements (tis ménysis) of the future events. Although similarities existed between the type and the antitype, the two events were not identical. Instead, the later events would exceed the former to the utmost extent (i.e. with an intensified meaning). ${ }^{25}$

After illustrating this first axiomatic thesis with his typological interpretation of the Exodus (Exodus 12:22f.29) and with quotations from First Corinthians 10:11 and Hebrews 9:13f., Theodore portrays the accounts of the biblical book of Jonah within this interpretive framework: "What happened in the case of blessed Jonah, the Prophet, was similar" (Theodore of Mopsuestia, Ion. prooem. 172,6f. Sprenger; translation Hill). The goal of his interpretation of the book is to present Jonah as a type of Christ (Theodore of Mopsuestia, Ion. prooem.; 173,6-11; 174,15-18 Sprenger) and, thereby, to manufacture the book's relevance for both himself and his Christian readership. It is of central importance that Theodore's typological interpretation of scripture gains its plausibility through the historicity of the types: Only the factual similarity (tis mimesis tốn prhagmátōn; 172,22-23 Sprenger) of the

24 With this line of reasoning, Theodore claims the proof-from-antiquity argument (“Altersbeweis") for the Christian faith. This particular argument, which always carried with it a ring of plausibility within the ancient world, regarded antiquity as a proof of truth. See Pilhofer 1990, 7-9, as well as the entire subsequent investigation, which includes supporting proofs.

25 See Goppelt 1939, 18f.: "Eine typologische Deutung dieser Objekte (sc. geschichtlicher Fakta) liegt vor, wenn sie als von Gott gesetzte, vorbildliche Darstellungen d.h. 'Typen' kommender, und zwar vollkommenerer und größerer Fakta aufgefasst werden. Fehlt zwischen Typ und Antityp die Steigerung, stellt also letzterer nur eine Wiederholung des ersteren dar, so kann von Fall zu Fall nur bedingt von Typologie geredet werden.” As Ostmeyer 2000, 112-131, has shown, this definition does not hold true for the New Testament texts and other Greekspeaking Church Fathers; it does, however, hold true for Theodore. Goppelt also correctly highlights: "Gegenstand typologischer Deutung können nur geschichtliche Fakta, d.h. Personen, Handlungen, Ereignisse und Einrichtungen sein, Worte und Darstellungen nur insofern, als sie von solchen handeln.” See also Horbury 1988, 766-767. 
type and the "antitype", of the foreshadowing and the predicted event, makes it possible to compare both side by side and thus (ek parhathéseōs; 172,12 Sprenger) observe the intensification (see Theodore of Mopsuestia, Ion. prooem.; 172,22-23 Sprenger). Accordingly, it is essential to understand the type (i.e. the historical events of the time) in order to understand the "antitype". Theodore's hermeneutical framework provides the reason for why he explains within his commentary "the things that happened at that time" (tá tote gegonóta; 176,22-28 Sprenger) and also his "attempt ... to construct a plausible and logical course of events" (Köckert 2011, 4). He achieves this through rationalizing and psychologizing paraphrases or providing supplements to the events reproduced in the biblical text. Two further characteristics of Theodore's interpretation of Jonah are intended to explain the biblical text on the literal level and to make the historicity of the narrative plausible: (1) the emphasis on divine providence and care and (2) the effort for a "godlike interpretation" that depicts God as omnipresent, omniscient, and gracious (see Köckert 2011, 4-8). Accordingly, Theodore presents an intellectual, scientific explanation of his pretext, ${ }^{26}$ which - by clarifying not only the central hermeneutical questions in the Prooemium but also by addressing detailed questions on the course of events within the actual verse-by-verse commentary - succeeds in overcoming the "expansion of the communicative situation" for both himself and his intellectual audience or readers in the Antiochian askētêrhion. He is thus able to both overcome the distance that separates him from his pretext and appropriate the old text for himself and his community.

As Theodore already made clear in the first lines of his commentary, his interpretive concerns - possibly due to the concurrent socio-religious situation in Antioch - lie chiefly in the relationship between the Old and the New Covenant, between Jews and Christians. Towards that aim, in the commentary's Prooemium he selectively highlights the features of the Jonah narrative that are fruitful for this line of inquiry, and neglects other aspects that are nonetheless present within the biblical text. ${ }^{27}$ The foundation for his interpretation comes at the very beginning of his exposition of the narrative: "when Jews were unbelieving and reluctant to heed his prophecies, God had him go instead to the nations." 28 Though it does not appear in the biblical book of Jonah, Theodore claims that Jonah was motivated to

26 The scientific aspect also manifests itself in individual stylistic features of the diatribe (e.g. 173.12-13 Sprenger) and in the examination of other research opinions (177.30-12 Sprenger).

27 In the Prooemium, Theodore e.g. highlights Jonah's appointment and flight, but does not mention Jonah's prayer in the sea monster's belly at all.

28 húto dé kaí tá kata tón makárhion gégonen Iōnán tón prhophêtēn, hón Iudaíōn apeithúntōn kaí prhosiesthai tás prhophēteías uk ethelóntōn, epí tá ethnē meteltheín parheskeúasen ho theós; Theodore of Mopsuestia, Ion. prooem. (172,7-8 Sprenger; translation Hill). 
go to Nineveh because he was despised in his homeland and among his own people. He further explains that Jonah's mission "to the peoples" (epí tá éthnē; 172.8 Sprenger), to Nineveh, was God's reaction to Israel's unbelief.

With these significant, supplementary framing details in place, Theodore meticulously carves out the structural parallels between the typologically predictive events in the Jonah narrative and the pre-announced events concerning Jesus Christ: just as Jonah spent three days and three nights in the belly of the sea monster and preached a message of repentance to the Ninevites, which they responded to with repentance, the same is also true of Jesus Christ, who spent three days and three nights in the earth (Matthew 12:40) and, after his resurrection, granted salvation to all peoples on account of their repentance (sōterhían; 172.15 Sprenger). Furthermore, just as the Jews rejected salvation through repentance in Jonah's day, so also it is now with the Jews who do not believe in Christ. ${ }^{29}$ The intensification of the type with the "antitype" - from "the belly of the sea monster” (en tếi koiliai tú kêtus) to "the heart of the earth" (en tếi karhdíai tếs gếs; cf. Matthew 12:40) and from the inhabitants of Nineveh to "all peoples" - cannot be overlooked. Theodore provides the structural parallels with a teleological meaning that is in accordance with God's divine economy, care, and providence: the events at that time occurred as typological foreshadowing in order that (hina; 172.12) "we" who recognize the foreshadowing ek parhathéseōs - analogous to the Ninevites - do not react with unbelief in Christ and his preaching of repentance.

Although the fate of unbelieving Jews does not at all appear in Theodore's pretext, he spends significant time on the subject within the Prooemium. The fact that he draws this information from outside of the text and proceeds to interpret it suggests that herein lies his true interest in the book of Jonah. Accordingly, in a psychological way Theodore places in Jonah's heart the belief that the "Jews" or Israelites who do not repent - in contrast to Nineveh's repentant response to Jonah's message - deserve the utmost punishment; so also the Jews who remain unbelievers - in contrast to the piety of the nations, which have been affected by the proclamation of Christ - are guilty of an even greater rejection (tến apobolén) of God than those in Jonah's time (174.29-175.16 Sprenger). The way Theodore portrays Jonah's reaction to Nineveh's repentance also seems to be of significance: he feels grief and lamentation (175.17-22 Sprenger). Theodore even assumes these emotions to be Jonah's motive to flee from God: by his flight, Jonah would attempt to avoid preaching to the inhabitants of Nineveh and, thereby, break the chain of events that would lead to the punishment of the Jews (176.7-10 Sprenger).

29 Theodore uses the same term (Iudaíoi) to describe both the ancient Israelites in Jonah's time and the contemporary Jewish population of Antioch. 
Theodore, on the basis of his interpretation of the biblical book of Jonah, determines the relationship between Jews and Christians by clearly showing that unbelieving Jews have been rejected and that salvation belongs to believing Christians. In a situation where Christians within their religious context in Antioch could not distinguish the difference between Judaism and Christianity, Theodore draws clear boundaries with his interpretation of the book of Jonah. Thus, he provides a formative contribution to the profile of the Christian identity of his readership. This interpretation, however, does not lead Theodore - in contrast to John Chrysostom - to a polemical or perhaps hostile tone against the Jewish population of the city. Instead, it leads him to an attitude of regret, even an attitude of pain and lament.

\section{Another metatext: Jerome of Stridon, Commentary on Jonah (396 CE)}

\subsection{Introductory questions: author and writing}

Eusebius Sophronius Hieronymus (Jerome) was born a few years before Theodore (c. $347 \mathrm{CE}$ ) in Stridon, which is located in the western part of the Roman Empire near Dalmatia. He was a "wanderer between worlds" because, during the first approximately 30 years of his life (up until $374 \mathrm{CE}$ ), he received his education within the metropolises of the Western Empire (Rome, Trier, Aquileia). In Rome, he might have seen the representations of Jonah in the catacombs. ${ }^{30}$ Afterwards, he moved east in $380 \mathrm{CE}$, where he - interrupted only by a short Roman interlude during the years 382-385 - became acquainted with Antioch and Constantinople, Palestine and Egypt. Finally, he founded a monastery in Bethlehem in 386 where he presided for almost forty years up until his death in 419/420 CE. In the 34 years he spent at the monastery, he devoted himself to asceticism and science ${ }^{31}-$ in this way he was similar to young Theodore of Mopsuestia. ${ }^{32}$ While in Bethlehem, he translated the book of Jonah from Hebrew into Latin (probably between 390 and $393)^{33}$ and in 396 authored his Jonah commentary (Commentarius in Ionam

30 Risse 2003, 11.

31 Jerome took his extensive library with him to Bethlehem, which included ancient authors, Christian works, Bible editions, and Bible commentaries. His library may be considered "one of the most important private collections of antiquity.” See Fürst 2011:1, 28-30, citation from 30.

32 Fürst 2002, 323-324.

33 According to Gryson 1994, XXIX-XXX, Jerome translated the Prophets from the Hebrew between 390 and 405; according to Rebenich 2002, 54, the Prophets were translated up to 392/93, 
prophetam), which belonged to a larger commentary on the Book of the Twelve Prophets that he wrote amid several interruptions. ${ }^{34}$ According to this date and the date for Theodore's Jonah commentary (see above), Jerome's work was published after Theodore's. Nevertheless, it is unlikely that Jerome knew of its existence (see Köckert 2011, 1 n. 3).

\subsection{The reader community in Bethlehem, Aquileia, and Rome}

In his Jonah commentary, Jerome addresses a learned readership residing in the Western Roman Empire. Like Theodore, Jerome feels that he is connected with his readership to form a community that received the biblical book of Jonah as authoritative for and written to them. We can see this, for example, in his use of the cohortative in his Commentarius in Ionam prophetam. Prooemium 2.10, with which he calls both himself and his readers - "us" - to lead a sinless life: "We understand what the Savior promised for our salvation in his passion. Let us not 'make Jesus a liar' (1 John 1:10). Let us be 'pure' (Isaiah 1:16), and separate from the filthiness of sins, so that he might offer us to God the Father as the sacrifices which he had vowed" (translation Hegedus). ${ }^{35}$ This inner connection exists despite the vast spatial distance between Jerome, in the "semi-barbaric" province of

as were the Psalter, the Books of Samuel and Kings, and Job, taking into account that "[b]oth the relative and the absolute chronology of his translations of the books of the Old Testament are controversial." The dating of Jerome's translation of the book of Jonah proposed here follows from the fact that he spent three years with other publications (Jerome, Ion. prooem.; 160. 1-8 Duval) and the fact that he references a reaction to his Jonah translation, thus indicating that Jerome made the translation before he wrote his commentary on Jonah (Ion. 4,6; 296. 132-298.143 Duval). In his tasks of translation and commentary, Jerome - as vir trilinguis puts his gift for languages to use (see Fürst 2011:1, 30). The question "how well could Jerome read Hebrew" is always and continually discussed within the research. We can assume, along with Risse 2003, 37, that Jerome "had a sufficient knowledge of Hebrew."

34 That Jerome interrupted his work on his commentary on the Book of the Twelve Prophets for three years and gave priority to numerous other publications (Jerome, Ion. prooem.; 161.1-8 Duval) shows that the Jonah commentary had no particular occasion but that Jerome worked on it as a part of a scientific commentary project. According to Rebenich 2002, 54, this "vast program of commentaries" was provoked by the criticism which his recourse to the Hebrew Old Testament (instead of the LXX) engendered.

35 Jerome of Stridon, Ion. 2.10; 256.381-385 Duval: Cernimus qui in sua passione Saluator pro nostra salute promiserit; non 'faciamus mendacem' Iesum (1 John 1,10). 'Mundi' (Isaiah 1.16) simus et ab uniuersis peccatorum sordibus separati, ut nos Deo Patri offerat uictimas quas uouerat (translation Hegedus). 
Palaestina prima (see Ronnenberg 2015, 104), and his reader community in Rome and Aquileia.

This is due to the fact that, although Jerome spent the second half of his life in the East, he nevertheless continued to orient himself to the West and maintained close relations with Roman nobles, who financially supported his scientific work and provided for the dissemination of his writings, which Jerome sent to Rome for publication (see Fürst 2011:1, 30). Even the official addressee of his Jonah commentary resided in the West: Chromatius, the bishop of Aquileia, was known to Jerome from the time of his residence in Aquileia (367-374; see Risse 2003, 11-12). He was a professional colleague, who also published numerous sermons in the form of a verse-by-verse exegesis with a typological-allegorical interpretation (Dümler 2002, 147).

Although Jerome only mentions Chromatius by name within his Jonah commentary, his intended readership was broader and can be characterized somewhat more precisely: he calls his readers "educated" and "clever" (eruditus/prudens lector; Ion. 1.3b). He presupposes that his readers have been classically educated, which is evidenced by his citations of the Andromeda myth (Ion. 1.3b) ${ }^{36}$ and Virgil (Ion. 1.8 quoting Aeneis 8.112-114), and Ovid (Ion. 2.2). ${ }^{37}$ The use of foreign Greek words and technical terminology ${ }^{38}$ also points to the level of education which he presumed his readership possessed. Concerning topics that his actual readership

36 See Ronnenberg 2015, 103-106. As Ronnenberg shows, Jerome draws from Josephus, De Bello Iudaico 3.9.3 and from his own point of view; see Jerome, Epistulae 108.8.2 (CSEL 55.314). 37 This passage, in which Jerome refers to Ovid's Metamorphoses, is of particular interest to the question of readership. In it, Jerome anticipates in a diatribic manner the possible objection contemporary readers - believing or unbelieving - might have to the book of Jonah that it is impossible for a man to remain unharmed within the stomach of a sea monster (in utero ceti). Jerome points the believing Jonah readers to the still greater challenges to the faith such as the three youths in the furnace (Daniel 3), the crossing of the Red Sea (Exodus 14:22-29), and the deliverance of Daniel from the lions' den (Daniel ${ }^{\text {vulg }}$ 14:31). For the unbelieving Jonah readers, however, he suggests that they should read Ovid's Metamorphoses and the entire Greek and Latin history, naming specifically a few "shameful fables" that they - as he polemically writes - believe and defend on the basis of the Almighty God, whereas they would not be able to attribute the same worth to the virtuous things as well ( . . cum turpibus credant potentiaque dei uniuersa defendant, eamdem uirtutem non tribuunt et honestis; Ion. 2.2; 226.74-76 Duval). The distinctive polemic of this passage demonstrates that Jerome does not address his work to the unbelieving Jonah reader, but only desires to give his own Christian readership arguments for similar disputes. See the analysis of Jerome's Ovid argument in Ronnenberg 2015, 132-135, who, however, erroneously assumes "critical voices" only "from the ranks of his Christian readership."

38 See for example Jerome, Ion. 1.9: hoc est perhátēs; Ion. 2.4a: iuxta anagōgến; Ion. 3.6-9: metaphorhikốs; Ion. 4.6: propter philokolókynthon. 
are interested in, Jerome learns of them second hand and can, therefore, only take a position some time after the fact, as is true of his dispute with a certain Canterius in Rome, who accused his translation of Jonah 4:6 ("Ivy") of being sacrilegious (Ion. 4.6).

\subsection{The commentary}

\subsubsection{Description of the text}

Jerome's Latin commentary on the book of Jonah contains a Prooemium, which comprises around $6 \%$ of the entire commentary, and a cursory, verse-by-verse commentary. In the verse-by-verse commentary, as a rule Jerome offers the biblical pretext as a lemma within the range of a verse, which is then followed by the actual commentary as paratext. The lemma is twofold: it consists of a Latin translation of the Hebrew text of Jonah as well as a Latin translation of the Greek LXXtranslation that is occasionally replaced by a concise comment: "LXX: similiter."39 Generally, the verse-by-verse commentary, now regarded as a metatext, is also divided into two parts: First, Jerome provides an explanation of the particular verse according to its historical sense $\mathrm{e}^{40}$ and then according to its spiritual sense. ${ }^{41}$ Often the verse-by-verse commentary follows the diatribic style, ${ }^{42}$ which itself reveals the conceptual background of a scientific school enterprise. The final feature of Jerome's commentary is the fact that it comes to an abrupt end without epilogue or doxology.

39 See for example Jerome, Ion. 1.3a; 172.37 Duval.

40 See for example Jerome, Ion. 4.6; 300.161 Duval.

41 Also referred to as tropological (for example Jerome, Ion. 1.1-2; 170.15 Duval), anagogical (Ion. 2.4a; 232.130 Duval), mystical (Ion. 2.11; 358.391 Duval), or proper sense (Ion. 3.3-4a; 262.44 Duval). These different expressions are largely synonymous in Jerome, see Risse 2003, 54.

42 Diatribe includes the stylistic device of the rhetorical question (Jerome, Ion. 1.9; 200.328 Duval; Ion. 1.14; 214.466-467 Duval), preemptive objections (Ion. 2.2; 224.56-58 Duval; Ion. 2.4a; 232.138 Duval), exclamations (Ion. 1.13; 212.436 Duval; Ion. 1.14; 212.457 Duval), adhortives (Ion. 1.15; 216.494 Duval; Ion. 4.6; 298.144 Duval), and imperatives (Ion. 2.1b; 222.40 Duval; Ion. 3.6-9; 274.176 Duval; Ion. 3.10; 278.234 Duval), as well as discussion of other research opinions (Ion. 2.1b; 222.28-37 Duval; Ion. 3.3-4a; 262.39-43 Duval; Ion. 4.10-11; 284. 271-273 Duval). 


\subsubsection{Strategies of appropriation}

Like Theodore, Jerome also establishes the framework for his commentary within the Prooemium. He understands that his task as a commentator is "to briefly and frankly (breuiter aperteque) explain that which is obscure" and to thoroughly discuss the meaning (sensum) of that which he interprets (Ion. prooem.; 162.21-25 Duval). In the course of his commentary, he adds the principle of breuitas, which he introduces as a generic feature of commentaries (Ion. 3.6-9; 276.185 Duval). ${ }^{43}$ The goal is to make the reader more confident in the text's interpretation. ${ }^{44}$ Immediately after his brief explanation of the circumstances surrounding the commentary's composition - its delayed publication due to the priority of other works - Jerome presents the most important guideline for his interpretation: Jonah is a typus Saluatoris, a "type of the Savior" and, by his stay within the belly of the sea monster, he depicted the resurrection of Christ (praefigurauit; Ion. prooem.; 160.10-12 Duval) in advance. In addition to this spiritual-typological interpretation $^{45}$ is Jerome's second pillar of interpretation: the explanation of the "historical foundations" (historiae fundamenta; Ion. prooem.; 166.66 Duval). The historical events recorded in Jonah function as the necessary foundation on which Jerome builds his spiritual interpretation. ${ }^{46}$ Finally, using stark "them" versus "us" language, Jerome sums up the entire book of Jonah by referencing the highest authority, Christ himself (Matthew 12:41): Unbelieving Israel, which is lost (them), is condemned, whereas repentant Nineveh, which has been made alive in Christ (us), will be saved (Jerome, Ion. prooem.; 166.76-168.89 Duval).

43 In his later Commentary on Daniel (407 CE), Jerome not only refers to the principle of breuitas - as he does in the commentary on the Twelve Prophets in reference to a commentator's responsibility to briefly explain the text - but also to the lemmata, which he produces, with omissions, per interualla (Jerome, Commentarius in Danielem prophetam. Praefatio; 775.81-86 Glorie); see Courtray 2007, 123-126.

44 This can be inferred from Jerome's description of a misunderstood commentary, which leaves the readers more uncertain (multo incertior) about the meaning of the text than before they read it (Jerome, Ion. prooem.; 162.17-21 Duval).

45 According to Jerome's own terminology this mode of interpretation is called "tropology" (tropologia, see Jerome, Ion. 1.1-2; 170.15 Duval); see Risse 2003, 52-55.

46 See Risse 2003, 39. Stylistically, both "pillars" form a kind of framework around Jerome’s comments on the task of the commentator. In this way, Jerome creates a greater distance between the first-class typological interpretation and the second-class (although foundational) historical interpretation. Jerome discusses the historicity of the person of Jonah within the Prooemium, both clarifying his genealogy by reference to other biblical sources and Jewish tradition and identifying the concrete, traditional location of Jonah's grave (Ion. prooem.; 162.26-166.65 Duval). 
Jerome's strategies for appropriating the old text, therefore, exist on three levels: (1) the level of the pretext, (2) the historical level, and (3) the typologicalspiritual interpretation. First, Jerome painstakingly strives to establish the authoritative version of the pretext. Towards this goal, he places within the lemmata section of the commentary both the Hebrew text of the book of Jonah and the LXX-version. He then offers his readers - who prior to his translation would have had only a vetus latina translation of Jonah ${ }^{\mathrm{LXX}}$ at their disposal - a new Latin translation of both the Hebrew and LXX-version. ${ }^{47}$ Also, in regard to authority, Jerome places the hebraica veritas above that of the LXX $\operatorname{text}^{48}$ and decides, on the basis of reasoned arguments, ${ }^{49}$ in favor of the text of the Hebrew Bible. ${ }^{50}$ In this way, he enables his readers to comprehend his judgment concerning the significance of the variants, even though they probably were not able to read either Hebrew or Greek. Ultimately, the result is a philological "production" of the authoritative text, which - in case there are divergent manuscripts or translations of the pretext circulating - forms the basis for every appropriation.

Second, on the historical level of interpretation of the scriptures, Jerome uses different means of explanation with which he both clarifies factual uncertainties that exist within the pretext or that have emerged as a result of the lengthy temporal distance between its origin and reception, and also illuminates the sense of the pretext at the literal level. ${ }^{51}$ For example: (a) He provides possible explanations of words or matters. (b) He employs his method of explaining Holy Scripture with Holy Scripture, a method that interprets the unclear passages in the book of Jonah with help from other biblical passages. (c) The psychological deepening of the narrative beyond what is contained within the pretext, usually in the form of a paraphrase or dramatization, transports the reader directly into the narrated event and

47 Jerome, Ion. 1.3b; 2.1a; 3,4b; 4.6 (among other places); see Risse 2003, 31-35; for information on Jerome's way of translating, see Risse 2003, 24-26.

48 Jerome, therefore, rejects the belief that the LXX is the inspired version, a view traditionally accepted in Early Christianity, see Schade 1910, 141-157.

49 A well-known and often discussed example in research is his translation of the word for the plant that provides Jonah with shade (Jonah 4:6) - in Hebrew qiyqāyōn (castor) and in Greek kolokýnthē (cucurbita/gourd) - with the Latin word hedera (ivy); see Jerome, Ion. 4.6; 296.122-300.170 Duval. See also Fürst 2011:2, 315-322.

50 See, for example, the contradictory details where Jonah predicts in Jonah ${ }^{\text {Hebr }} 3: 4 \mathrm{~b}$ that Nineveh still has 40 days to repent until its destruction but gives Nineveh only 3 days in the LXX version (see for example Jerome, Ion. 3,4b; 264.59-266.76 Duval). Astonishingly enough Jerome does not discuss the difference between Jonah ${ }^{\text {Hebr }} 1.9$ and Jonah ${ }^{\mathrm{LXX}} 1.9$, but restricts himself to discussing the wording in Jonah ${ }^{\mathrm{Hebr}} 1.9$.

51 See the more detailed presentation in Risse 2003, 45-49. 
makes it comprehensible to him. ${ }^{52}$ (d) As a bridge to the typological-spiritual interpretation of scripture, Jerome often expounds upon the meaning of names. The most prominent example in his Jonah commentary is the double meaning of the name Jonah: on the one hand it means "dove" (columba) and, therefore, prefigures Jesus Christ, on whom the Holy Spirit descended in the form of a dove; on the other hand it means "the sufferer" (dolens) and, therefore, also predicts Jesus Christ, who suffered by "our” injuries (Jerome, Ion. 1.1-2; 170.18 Duval). Jerome is putting this in a nutshell by saying: Dominus noster Ionas (Jerome, Ion. 1.1-2; 170.15 Duval). For this explanation, Jerome draws from a lexicon of the meaning of biblical names, which he had translated in $389 .^{53}$

Third, on the typological-spiritual level of interpretation - the supreme aim of his Jonah commentary - Jerome interprets, verse-by-verse, the wording of the pretext which he by now has established (level 1) and explained (level 2) as a typological foreshadowing of the Christ event. He, therefore, stands in the Alexandrian tradition of the multiple senses of scripture and probably draws from Origen's Commentary on Jonah, of which he possessed a copy. ${ }^{54}$

Because of his belief in the multiple senses of scripture, he is open to the possibility of multiple meanings of a biblical passage. Accordingly, he understands Jonah's flight as a type of the incarnation of Christ, which he interprets as a "flight from heaven" (Ion. 1:3a; 176.86-88 Duval). A little later, however, he claims that Jonah's flight refers to mankind's rejection of God's commandments and its (mankind's) flight from God (Ion. 1.4; 186.185-189 Duval). As an experienced commentator, Jerome is aware of the limitations of typological interpretation, which is evident by the fact that he does not relate every verse and every detail of the biblical book of Jonah to Christ, but allows that some passages "have their own interpretations" (haec testimonia suas interpretationes habent, Ion. 1:3b; 184.167 Duval). ${ }^{55}$

In addition to his interpretation of Jonah as a type of Christ, Jerome's spiritual-typological - in his own terminology: tropological - interpretation of the city of Nineveh is important for understanding his appropriation of the biblical

52 Occasionally, he chooses the first person singular for this aim; cf. Jerome, Ion. 1.12; 206. 391-208.398 Duval, where Jerome deepens the meaning of Jonah 1:12 (i.e. Jonah's request that the sailors cast him into the sea).

53 De nominibus Hebraicis (CCL 72.59-161).

54 See Duval 1985, 13. Although Jerome refutes Origen's apokatastasis doctrine (Ion. 3.6-9; 272.139-276.187 Duval), he considers himself “wealthy like Croesus” because he owns Origen's Commentary on the Twelve Prophets (see ibidem).

55 See also Jerome, Ion. prooem.; 166.66-69 Duval. 
book of Jonah. ${ }^{56}$ With help from the explanation of the description of Nineveh as "the beautiful (city)", 57 he interprets Nineveh as the world of the peoples resp. the non-Jews (mundus gentium, Ion. 1.1-2; 170.15-24 Duval). As Jerome explains, Jonah was sent to the non-Jews in order to preach to them a message of repentance (Ion. 1.1-2; 168.8-10 Duval); typologically, this means that the Lord, the true Jonah, was also sent to preach to the world/the non-Jews (Ion. 3.4b; 266.77-78 Duval). Since the Ninevites repent and believe, Jerome can interpret the city of Nineveh as the Church (Ion. 4.10-11; 314.310-311 Duval), the community of believers. The textual pragmatic that Jerome sets forth through his commentary on the book of Jonah lies in the affirmation (Vergewisserung): just as God preserves Nineveh from destruction because of its repentance and faith, so also will he preserve the Church from destruction because of its repentance and its belief.

Jerome also draws out the other side of this tropology with scientific consistency: on the historical level, he argues that the repentance of the inhabitants of Nineveh (i.e. those who believed Jonah's sermon) led to Israel's condemnation because they, in contrast to Nineveh, remained in their wickedness (Ion. 1.1; 168. 8-10 Duval). Jonah, by the inspiration of the Holy Spirit, knew about this state of affairs (Ion. 1.3a; 172.38-39 Duval). On the tropological level, this would mean that the belief in Jesus Christ is the decisive factor determining salvation or condemnation, and that the believing Church will receive salvation and the non-believing Jews will receive condemnation. Jerome, however, only formulates this sharp distinction in the Prooemium (see above). In the verse-by-verse commentary, directed by his pretext, Jerome elaborates that the historical sense of the passage teaches that Jonah mourned over Israel's condemnation (for example Ion. 4.1; 286.5-10 Duval) and that - on the spiritual-typological level - Christ also weeps over Jerusalem (Ion. 4.9; 308.247-250 Duval; see Ion. 4.1; 286.16 Duval; Ion. 1.5a; 188. 210-211 Duval).

\section{The appropriation of the book of Jonah by Theodore of Mopsuestia and Jerome of Stridon}

Theodore and Jerome, two different authors in two different places, receive the same text - the biblical book of Jonah - at about the same time. This means

56 Hier. Ion. 1.1-2; 170.15 Duval: Iuxta tropologiam ...

57 Jerome hints at the Greek word kósmos for mundus, stating that in Greek the world was called kósmos because of its beauty, see Jerome, Ion. 1.1-2; 170.22-24 Duval. 
that they face the same challenge of adapting the old, at times incomprehensible, text which not always seems to be immediately relevant for the present age but is nevertheless canonical, and also demonstrates to their readership the possibilities of appropriation.

Both authors know and use both the historical and the typological-spiritual interpretations of scripture. For Theodore, this forms the framework within which he draws his historical commentary; Jerome, however, endeavors to consider the interpretation of both contexts side-by-side since the superior spiritual interpretation of scripture is built upon the foundation of its historical interpretation. Jerome is particularly interested in the production and translation of the authoritative pretext because his readership must, as a first step in appropriating the text, overcome the hurdle of its foreign language. For Theodore's Greek speaking readership, this issue does not exist because his commentary is based only upon the LXX text. For both authors, the clear profiling of the relationship between Jews and Christians is a central theme against the background of identifying and affirming the character of the Christian community. Theodore, on the basis of his methodological procedure, reads the book of Jonah more selectively than Jerome with regard to this specific question; Jerome's interpretation is more complete, differentiated, and intrinsically inconsistent by virtue of his double interpretation of every single verse. This is seen, among other places, in his interpretations of Israel and the Jews where he - along with Theodore - expresses grief for the lost people of God, but in other places, depending on the verse interpreted, chooses formulations "of a biting sharpness." 58

In many ways, both commentaries demonstrate that the individual appropriation of the old, canonical book of Jonah by Theodore and Jerome is based on the elevation of a spiritual, Christian sense, which follows from a specific, dogmatic framework of typology. The spiritual interpretation not only takes place beside the historical interpretation, but also takes the historical sense into its service. Thus, the old biblical text gains a wholly new meaning and relevance for its Christian readership in the 4th century CE.

58 Risse 2003, 75. 


\section{Bibliography}

\section{Sources}

\section{Jerome}

Hieronymus. Commentariorvm in Danielem libri III (IV), ed. F. Glorie. Corpus Christianorum Series Latina 75 A. Turnhout. 1964.

Hieronymus. Commentarius in lonam Prophetam. Kommentar zu dem Propheten Jona, übersetzt und eingeleitet von Siegfried Risse. Fontes Christiani 60. Turnhout. 2003.

Hieronymus. Epistulae LXXI-CXX, ed. Isidorus Hilberg. Corpus Scriptorum Ecclesiasticorum Latinorum 55. Berlin 1912/1996.

Jérôme. Commentaire sur Jonas, introduction, texte critique, traduction et commentaire par Yves-Marie Duval. Sources Chrétiennes 323. Paris. 1985.

Jerome's Commentary on Jonah, translation with introduction and critical notes by Timothy Michael Hegedus. Ann Arbor, MI. 1991.

\section{John Chrysostom}

Johannes Chrysostomus. Adversus loudaios, ed. J.-P. Migne. Patrologiae Graecae cursus completus 48. Paris. 1862. 843-942.

\section{Josephus}

Josephus, F. De bello Judaico: Zweisprachige Ausgabe der sieben Bücher, ed. O. Michel. 2 vols. Darmstadt. 1963/1969.

\section{Theodoret of Cyrus}

Theodoret. Kirchengeschichte, ed. L. Parmentier, 3rd ed. G. C. Hansen. Die griechischen christlichen Schriftsteller der ersten Jahrhunderte. Neue Folge 5. Berlin. 1998.

\section{Theodore of Mopsuestia}

Theodore of Mopsuestia. Commentary on the Twelve Prophets, introduction and translation by Robert C. Hill. The Fathers of the Church 108. Washington, D.C. 2004.

'Theodori Mopsuesteni “Commentarius in Ionam".' In H. N. Sprenger, Theodori Mopsuesteni Commentarius in XII Prophetas. Einleitung und Ausgabe. Göttinger Orientforschungen V,1, Teil II. Wiesbaden. 1977. 169-190.

\section{Literature}

Assmann, Jan 1995. 'Text und Kommentar: Einführung.' In Text und Kommentar: Archäologie der literarischen Kommunikation IV, ed. Jan Assmann, Burkardt Gladigow. München. 9-33.

Boyarin, Daniel 1999. Dying for God: Martyrdom and the Making of Christianity and Judaism. Figurae: Reading Medieval Culture. Stanford.

Bracht, Katharina 2014. Hippolyts Schrift In Danielem: Kommunikative Strategien eines frühchristlichen Kommentars. Studien und Texte zu Antike und Christentum 85. Tübingen. 
Bruns, Peter 2002. 'Theodor von Mopsuestia.' In Lexikon der antiken christlichen Literatur, ed. S. Döpp, W. Geerlings. 3. Aufl. Freiburg i.Br. 678-680.

Courtray, Régis 2007. 'Der Danielkommentar des Hieronymus.' In Die Geschichte der DanielAuslegung in Judentum, Christentum und Islam: Studien zur Kommentierung des Danielbuches in Literatur und Kunst, ed. Katharina Bracht, David S. du Toit. Beihefte zur Zeitschrift für die alttestamentliche Wissenschaft 371. Berlin. 123-150.

Dassmann, Ernst 1998. 'Jonas B II/IV', Reallexikon für Antike und Christentum 18. 678-689.

Dresken-Weiland, Jutta 2010. Bild, Grab und Wort: Untersuchungen von Jenseitsvorstellungen von Christen des 3. und 4. Jahrhunderts. Regensburg.

Dümler, Bärbel 2002. 'Chromatius von Aquileia.' In Lexikon der antiken christlichen Literatur, ed. Siegmar Döpp, Wilhelm Geerlings. 3. Aufl. Freiburg i.Br. 147.

Dunn, James D. G. 1996. The Parting of the Ways: Between Christianity and Judaism and their Significance for the Character of Christianity. 2nd edition. London.

Duval, Yves-Marie 1973. Le livre des Jonas dans la littérature chrétienne grecque et latine: Sources et influence du Commentaire sur Jonas de saint Jérôme. Études Augustiniennes. Paris.

Duval, Yves-Marie 1985. 'Introduction.' In Jérôme. Commentaire sur Jonas: Introduction, texte critique, traduction et commentaire par Yves-Marie Duval. Sources Chrétiennes 323. Paris. 9-148.

Fuhrer, Therese 2002. 'Diodor von Tarsus.' In Lexikon der antiken christlichen Literatur, ed. Siegmar Döpp, Wilhelm Geerlings. 3. Aufl. Freiburg i.Br. 199-200.

Fürst, Alfons 2002. 'Hieronymus.' In Lexikon der antiken christlichen Literatur, ed. Siegmar Döpp, Wilhelm Geerlings. 3. Aufl. Freiburg i.Br. 323-330.

Fürst, Alfons 2011:1. 'Hieronymus. Theologie als Wissenschaft.' In Von Origenes und Hieronymus zu Augustinus: Studien zur antiken Theologiegeschichte, ed. Alfons Fürst. Arbeiten zur Kirchengeschichte 115. Berlin. 25-42.

Fürst, Alfons 2011:2. 'Kürbis oder Efeu? Zur Übersetzung von Jona 4,6 in der Septuaginta und bei Hieronymus.' In Von Origenes und Hieronymus zu Augustinus: Studien zur antiken Theologiegeschichte, ed. Alfons Fürst. Arbeiten zur Kirchengeschichte 115. Berlin. 315-322.

Fürst, Alfons 2011:3. 'Jüdisch-christliche Gemeinsamkeiten im Kontext der Antike: Zur Hermeneutik der patristischen Theologie.' In Von Origenes und Hieronymus zu Augustinus: Studien zur antiken Theologiegeschichte, ed. Alfons Fürst. Arbeiten zur Kirchengeschichte 115. Berlin. 293-314.

Golka, Friedemann W. 2001. 'Jona/Jonabuch', Religion in Geschichte und Gegenwart 4. 567-569.

Goppelt, Leonhard 1939. Typos: Die typologische Deutung des Alten Testaments im Neuen. Beiträge zur Förderung christlicher Theologie. 2. Reihe Sammlung wissenschaftlicher Monographien 43. Gütersloh.

Gryson, Roger 1994. 'Preface to the First Edition.' In Biblia Sacra iuxta vulgatam versionem, ed. Robert Weber. 4. rev. ed. by Roger Gryson. Stuttgart. XXIX-XXXIII.

Hahn, Johannes 1996. 'Die jüdische Gemeinde im spätantiken Antiochia.' In Jüdische Gemeinden und Organisationsformen von der Antike bis zur Gegenwart, ed. Robert Jütte, Abraham P. Kustermann. Aschkenas Beiheft 3. 57-89.

Heckel, Theo K. 2011. 'Jonas. Jona. Einleitung.' In Septuaginta Deutsch: Erläuterungen und Kommentare zum griechischen Alten Testament, ed. Martin Karrer, Wolfgang Kraus. Vol. 2: Psalmen bis Daniel. Stuttgart. 2394-2404.

Hill, Robert C. 2001. 'Theodore of Mopsuestia: Interpreter of the Prophets', Sacris Erudiri 40. 107-129. 
Hill, Robert C. 2004. 'Introduction.' In Theodore of Mopsuestia. Commentary on the Twelve Prophets, translated by Robert C. Hill. The Fathers of the Church 108. Washington, D. C. 1-34.

Horbury, William 1988. 'Old Testament Interpretation in the Writings of the Church Fathers.' In Mikra: Text, Translation, Reading and Interpretation of the Hebrew Bible in Ancient Judaism and Early Christianity, ed. Martin J. Mulder, Harry Sysling. Assen/Maastricht. 727-787.

Köckert, Charlotte 2011. 'Der Jona-Kommentar des Theodor von Mopsuestia. Eine christliche Jona-Auslegung an der Wende zum 5. Jahrhundert (mit einer Übersetzung des Kommentars).' In Der problematische Prophet: Die biblische Jona-Figur in Exegese, Theologie, Literatur und bildender Kunst, ed. Johann Anselm Steiger, Wilhelm Kühlmann. Arbeiten zur Kirchengeschichte 118. Berlin. 1-38.

Kondoleon, Christine 2000. 'The City of Antioch: An Introduction.' In Antioch. The Lost Ancient City, ed. Christine Kondoleon. Princeton, NJ. 3-12.

Lindemann, Andreas 2001. 'Art. Judentum und Christentum III. Neues Testament und ältestes Christentum. IV. Alte Kirche', Religion in Geschichte und Gegenwart ${ }^{4}$ 4. 630-633.

Ostmeyer, Karl-Heinrich 2000. 'Typologie und Typos: Analyse eines schwierigen Verhältnisses', New Testament Studies 46. 112-131.

Paul, J. 1970. 'Jonas', Lexikon der christlichen Ikonographie 2. 414-421.

Pilhofer, Peter 1990. Presbyteron kreitton: Der Altersbeweis der jüdischen und christlichen Apologeten und seine Vorgeschichte. Wissenschaftliche Untersuchungen zum Neuen Testament 39, Reihe 2. Tübingen.

Rebenich, Stefan 2002. Jerome. The Early Church Fathers. London.

Risse, Siegfried 2003. 'Einleitung.' In Hieronymus: Commentarius in lonam Prophetam. Kommentar zu dem Propheten Jona, übersetzt und eingeleitet von Siegfried Risse. Fontes Christiani 60. Turnhout. 9-86.

Ronnenberg, Karsten C. 2015. Mythos bei Hieronymus: Zur christlichen Transformation paganer Erzählungen in der Spätantike. Hermes-Einzelschriften 108. Stuttgart.

Rüpke, Jörg 2015. 'The "Connected Reader” as a Window into Lived Ancient Religion: A Case Study of Ovid's Libri fastorum', Religion in the Roman Empire 1. 95-113.

Schade, Ludwig 1910. Die Inspirationslehre des Heiligen Hieronymus: Eine biblischgeschichtliche Studie. Freiburg i.Br.

Schart, Aaron 2011. 'Dodekapropheton. Das Zwölfprophetenbuch. Einleitung.' In Septuaginta Deutsch: Erläuterungen und Kommentare zum griechischen Alten Testament, ed. Martin Karrer, Wolfgang Kraus. Vol. 2: Psalmen bis Daniel. Stuttgart. 2275-2286.

Schäublin, Christoph 1974. Untersuchung zu Methode und Herkunft der antiochenischen Exegese. Theophaneia 23. Köln.

Schäublin, Christoph 1981. 'Diodor von Tarsus', Theologische Realenzyklopädie 8. 763-767. Sprenger, Hans Norbert 1977:1. 'Einleitung.' In Theodori Mopsuesteni Commentarius in XII Prophetas: Einleitung und Ausgabe, ed. Hans Norbert Sprenger. Göttinger Orientforschungen V,1. Teil I. Wiesbaden. 1-174.

Zenger, Erich 2016. 'Das Zwölfprophetenbuch.' In Einleitung in das Alte Testament, ed. Erich Zenger et al. 9th edition ed. Christian Frevel. Kohlhammer Studienbücher Theologie 1,1. Stuttgart. 630-709. 